\title{
$1 G$ Needs Are Student Needs: A Mixed-Methods Approach to Understanding the Experiences of First-Generation College Students
}

\author{
Emily Daly, Joyce Chapman, Arianne Hartsell-Gundy, and Brenda Yang \\ Duke University, USA
}

\begin{abstract}
How can Duke University in general-and the Duke Libraries in particular-further support the success of its first-generation $(1 \mathrm{G})$ college students? To explore this question, a cross-departmental team of library staff conducted six focus groups with $1 \mathrm{G}$ students during the 2017-2018 academic year and analyzed responses from the biennial student survey (overall $\boldsymbol{N}=2,381)$ with the $1 G$ status demographic $(\boldsymbol{N}=127)$. Overall, the existing research on $1 \mathrm{G}$ experiences generalizes to students at Duke. While $1 \mathrm{G}$ students' experiences are not monolithic, we identified nine findings relating to $1 \mathrm{G}$ students' experiences on campus and in the libraries. These findings identify patterns of common difficulties among students and suggest points to leverage for intervention and support. This paper summarizes the research team's methodology and findings and describes ways that library staff and campus stakeholders have implemented the team's recommendations to improve library services and access for $1 \mathrm{G}$ students. While this study focused on the experiences and needs of $1 \mathrm{G}$ students, it should be emphasized that $1 \mathrm{G}$ challenges are student challenges: support or expansions of campus and library services targeted toward $1 \mathrm{G}$ students will help all students succeed.
\end{abstract}

\section{Background}

First-generation students, many of whom refer to themselves as $1 \mathrm{G}$, can encounter experiences unique to their background in a university setting. While many are successful, $1 \mathrm{G}$ students typically do not have family experience to draw on in navigating college life. They are also more likely to hold financial and other responsibilities that impact their academic and social life.

After analyzing Duke students' responses to the 2015 COFHE Enrolled Student Survey, ${ }^{1}$ library staff became interested in learning more about $1 \mathrm{G}$ students and determining whether studies conducted elsewhere translated to Duke students' experiences. A team of staff from Research and Instructional Services and Assessment and User Experience studied a subset of Duke's 1G population to learn more about these students' university and library experiences. In September and October 2017, the team conducted four focus groups with first-generation college students at Duke, followed by two additional focus groups with firstyear students in the spring of 2018.

Prior to planning the focus groups and survey, the team contacted the Duke Office of Access and Outreach $(\mathrm{A} \& \mathrm{O})^{2}$ to understand the overall landscape for Duke's $1 \mathrm{G}$ students. The team learned that $1 \mathrm{G}$ students comprise approximately $10 \%$ of all students, which translates to roughly 170 students in each class. About $20 \%$ of $1 \mathrm{G}$ students (60 incoming) are offered admission to the Rubenstein Scholars (RS) ${ }^{3}$ program, a meritbased program offering a full scholarship and additional funding for services such as parent visits. While all $1 \mathrm{G}$ students have access to a set of core services-including a pre-orientation program, a faculty lunch series, social outings, and support from A\&O-RS receive additional support and onboarding, and program evaluation conducted thus far has primarily occurred within the RS program. This team chose to study both RS and non-RS $1 \mathrm{G}$ students.

\section{Methodology}

The team first contacted the Institutional Review Board (IRB) to verify that IRB review was not necessary for the project, given that the team does not plan to retain identifying information or use findings to attempt to draw generalizable conclusions (rather, the team intends to use findings for internal improvement only). The team then gathered and reviewed relevant literature (Appendix A, Selected bibliography) and reached out to colleagues to discuss similar work that had been performed at other university libraries (e.g., survey 
and focus groups conducted with $1 \mathrm{G}$ and non-1G students by Stacy Brinkman and her colleagues at Miami University ${ }^{4}$ ).

In consultation with $\mathrm{A} \& \mathrm{O}$, the team formed a recruitment strategy and planned the content of the focus groups (Appendices B and C, Focus group scripts). The team decided to conduct six focus groups: three with upperclassmen, one with RS upperclassmen, and two with first-years. Working with A\&O and staff in the Institutional Research Office, the team sent focus group invitations (Appendix D, Recruitment email) to 411 $1 \mathrm{G}$ sophomores, juniors, and seniors in the fall of 2017. The recruitment email resulted in 28 volunteers, 16 of whom were scheduled for focus groups in September. We were unable to schedule a seniors-only group and so instead had three mixed focus groups. The RS recruitment email was sent to 27 students and resulted in five volunteers, two of whom were able to be scheduled for a focus group in October.

Recruitment for first-year focus groups was conducted in the spring of 2018, to avoid the potential stress of attending a focus group during one's first semester at Duke, and to allow more time for reflection. Similar email procedures were followed.

Figure 1: Structure of focus groups conducted with 1G students during the 2017-18 academic year

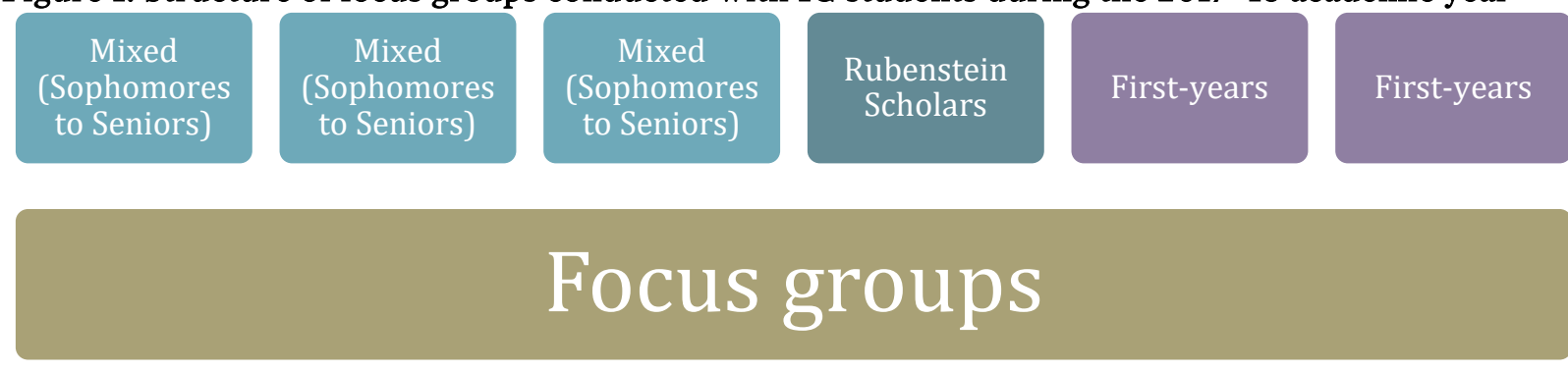

Four focus groups for sophomores, juniors, and seniors were conducted in the fall semester; two focus groups for first-year students were conducted in the spring.

Each of the five non-RS focus groups was attended by two DUL staff members: one to moderate and another to take notes. The two-person RS focus group was attended only by a moderator, so as not to overwhelm students with a large number of staff. All focus groups were recorded with an audio recorder to facilitate data analysis and note taking; recordings were kept in a secure location and erased once analysis was complete.

In addition to focus group findings, the team analyzed data from a 2018 university-wide survey. The 2018 survey included questions intended to illuminate how all students feel about using library spaces and services. Probes included the following: "The library is an important part of my experience at Duke"; "For me, the library is a welcoming place"; "I am confident in my ability to use library resources." ${ }^{5}$ Library staff were particularly interested in comparing $1 \mathrm{G}$ students' survey responses to these types of questions to the responses from the general student population. Library staff did not conduct special recruitment to increase the participation of $1 \mathrm{G}$ students for the university-wide survey; $1 \mathrm{G}$ students were simply included alongside others in the sample provided by staff in the Institutional Research Office.

Individual emails were sent to each student in the sample, asking them to participate in the survey. Two hundred thirty-eight (238) 1G students were included in the sample, representing $5.5 \%$ of the total student sample and $10.4 \%$ of the undergraduates included in the sample. One hundred twenty-seven (127) $1 \mathrm{G}$ students responded to the survey (including students in the sample and students who answered a second version of the survey at an open URL). 1 G students comprised $10 \%$ of the 1,254 total undergraduate respondents. This accurately reflects the composition of the total undergraduate population. $1 \mathrm{G}$ students' survey responses were analyzed and compared to responses from the general student population. 


\section{General findings}

\section{Finding l. Students perceive a dearth of academic and social information capital.}

We asked all focus group participants the following, "Have you ever felt like other people around you know things about college that you don't know about?" Each time, the response from the group was laughter, and an overwhelming expression of, "Yes, of course, all the time." One student captured the experience of her continuing-generation peers-who have family members' experiences and knowledge to draw on in navigating college-having access to a stunning amount of information that was inaccessible to her:

"Who told you that? Have you been told your whole life you have to do this? Was there an info session I missed?"

Students repeatedly referred to Duke's demanding academic environment and the abrupt transition from their high school habits to the expectations of the classrooms of an elite university. Students reported that they gained knowledge about how to succeed academically (such as how to study or pace coursework across the semester) over time, rather than coming to Duke in possession of much of that knowledge already as many continuing-generation peers seemed to do. At times, Duke staff also take for granted how much knowledge incoming students have.

"When I first came here, I was just so shocked by how everybody else knew how to succeed in college level classes."

"I made an appointment with a DAE [Director of Academic Engagement in the Academic Advising Center]. She threw a lot of information at me. She spewed words at me and I had to go and Google what she said."

Information capital is not limited to classrooms; it is also used in social contexts and in navigating college life. 1G experiences are diverse: while some students reported feelings of isolation, others described feeling supported through orientation programs and a lively community on Duke's East Campus, where many undergraduates live.

While $1 \mathrm{G}$ students perceive that continuing-generation students are able to rely on family to guide them through myriad informational and financial challenges encountered in college, $1 \mathrm{G}$ students do not have access to this information from their parents. In addition, they sometimes feel unable to share the stress of college with their parents.

"You have the pressure of pretending 'I'm okay.' My parents are so proud of me that I can't tell them what's really going on."

How do students describe overcoming this information gap? While we suspect this gap is never perceived to be completely filled, it can be assuaged through mentorship at multiple levels. Early experiences with supportive upperclassmen, graduate students, staff, or faculty are key lifelines for gaining information.

\section{Finding 2. Finances are stressful, and an early source of feeling unwelcome.}

Past research suggests that feeling that one does not belong is a global concern for first-years adjusting to life on a college campus, and one particularly poignant for $1 \mathrm{G}$ students. Duke is no exception to this pattern. Several focus group participants shared comments they received from their peers after revealing that they were the first in their families to attend college. Such comments can exacerbate feelings of not belonging.

"Oh you're smart for a first-generation student. I never would have known!"

First-year focus group participants quoted other early encounters with roommates or colleagues that continued to sting. Many of these comments reflect the fact that financial security is one of the starkest differentiators between many $1 \mathrm{G}$ students and their peers at Duke. 
"There's definitely a mentality that exists at Duke that middle class is poor and lower class is even worse. Not that everybody is like that, but it certainly exists."

When $1 \mathrm{G}$ students reveal aspects of their own financial circumstances to their peers, they receive blowback in several ways. For example, a few students shared that their financial aid was stigmatized, with other students suggesting that those who receive aid are very "lucky" to pay so little, or stating explicitly their own significant costs of attendance, possibly to engender shame or guilt. These experiences are formative, alienating, and angering.

"You don't understand: my family makes half of what it costs a year to come to this school. I know it sucks that your parents are paying 40 grand a year or whatever, but some of us don't even make 40 grand a year."

Overall, the gap between financial backgrounds makes itself clearly known when students arrive on campus, in ways big and small, from abrasive comments to difficulties purchasing meals or trouble participating in social events (e.g., joining other students going bowling or to the movies). While academic breaks and summers are important times to step away from classwork to refuel or reconnect with loved ones for most students, undertaking exotic travels or even just returning home to see family during the holidays is not an option for $1 \mathrm{G}$ students with financial stressors, many of whom must work or do not have families who can pay to support them.

"Some of us don't have credit cards that we can use. Some of us don't have $\$ 25$ to add to our FLEX account. Some of us are helping our parents [financially] back home... Just because you go to Duke doesn't mean you can afford to live at Duke all the time."

\section{Finding 3. An ecosystem of supportive offices and people on campus is critical, but knowledge of and willingness to access resources takes time.}

The landscape described above is important to understand because it is the one $1 \mathrm{G}$ students step into when they arrive at Duke. However, peer attitudes and financial impediments are difficult intervention points. The unwelcoming comments described above come, after all, from other young adults, learning in their own way to adjust to a new environment. In contrast, faculty, older peers, and staff are better positioned to be support systems native to the institution:

"When you go to Duke resources, people are more than happy to help you. Adults at Duke are much more receptive and much more understanding of our issues as first-generation students.”

In general, students spoke warmly of the many services, programs, and offices offered on campus. This included the Office of A\&O, resident assistants (RAs), peer advisors, a close community on East Campus as freshmen, pre-orientation, the Women's Center, the Financial Aid office, Counseling \& Psychological Services (CAPS), Duke Reach, and cultural student groups. 
Figure 2: Word cloud of campus spaces that focus group respondents identified as safe and welcoming

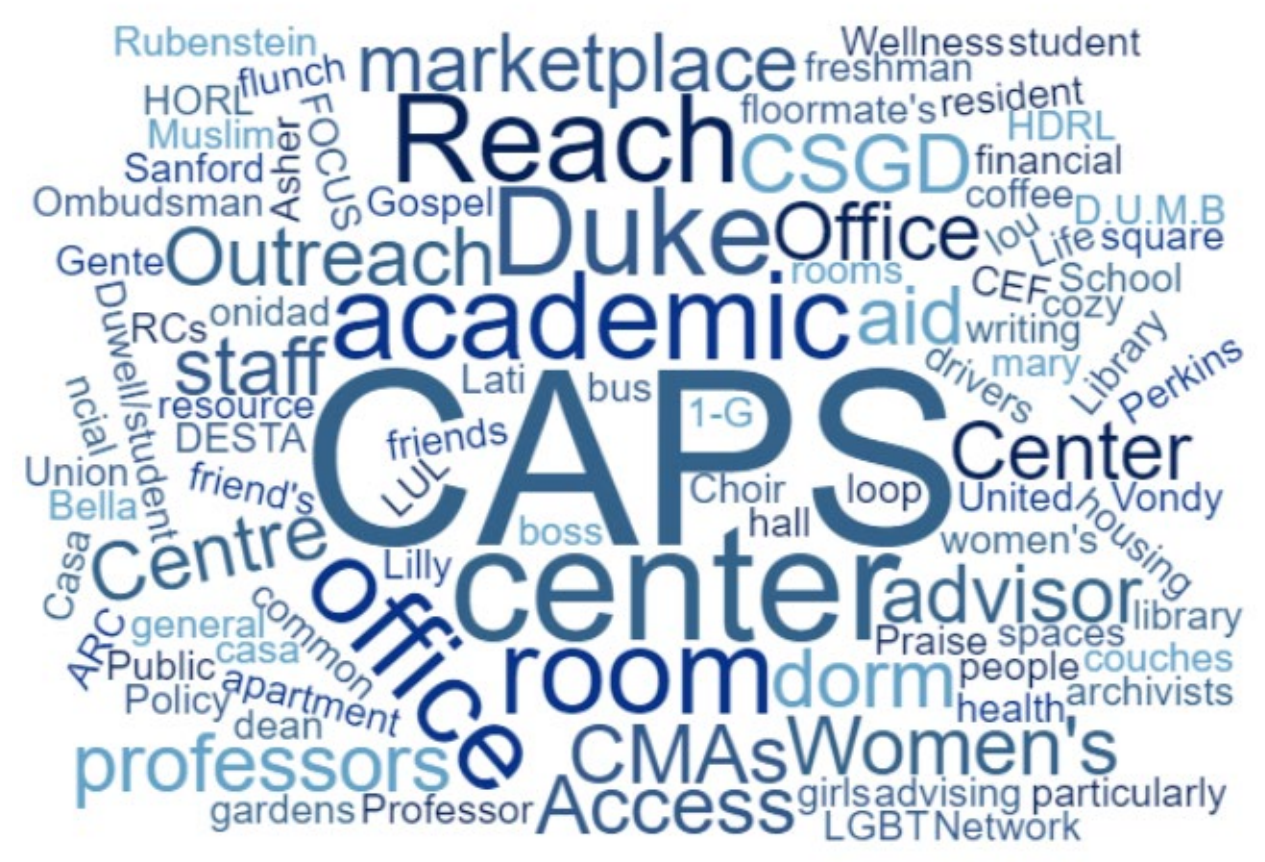

The staff in the Office of A\&O were mentioned frequently. Students praised staff members, citing their open door policy, knowledge, and willingness to offer genuine and consistent support. A\&O's help navigating financial aid helps students access opportunities, such as study abroad, which would have otherwise remained out of reach. Students reported stigma associated with visiting several resources, such as CAPS, the Academic Resource Center (ARC), the Women's Center, and identity centers. Other students reported that finding the right peer support network is not necessarily straightforward.

\begin{abstract}
"I mean, I'm [Latino], but going [to Mi Gente] once, I felt really off... When I went later [in the semester] to try to join, they already had their group and clique..."

"Same thing with the Queer Alliance here at Duke. I find them to be very exclusionary, very clique-y. (Other focus group members: 'Yeah.' 'They are.' 'Very wealthy, too.')...So, even the groups that are supposed to be for minorities, they should do better at being open."
\end{abstract}

\title{
Finding 4. The cost of textbooks is a special pain point.
}

In most focus groups, students shared the challenge, stress, and fear of purchasing expensive textbooks. This anxiety about textbooks rests on top of an ongoing concern about finances. Some students noted that they serve as a primary source of support for their own parents, contributing to the pressure they feel to be successful at Duke. Students described the systems they had developed over the years-often through trialand-error-to circumvent textbook expenses. This included social networks (e.g., Facebook groups for textbook exchanges and purchases), renting or borrowing the textbook and scanning its entirety, using the library's course reserves or Textbooks on Reserve Program, and spending a long time searching for free online PDFs of textbooks. Students described extensive efforts to find affordable copies, taking great pains to maintain their workbooks so they could re-sell them at the end of the semester, and to locate upper-level textbooks that were not available through Textbook on Reserve.

“[Laughter] I've never researched so hard as when I'm looking for a digital version of a textbook!” 
Students who knew about and utilized the Textbooks on Reserve Program made special note of its impact and importance in alleviating some financial burden.

"The textbook rental program has been really important and impactful for me...To get them here and be able to rent them out for 3 hours has been perfect. It's really important to have that."

Results from the library's biennial student survey also support the idea that the Textbooks on Reserve Program is particularly important for $1 \mathrm{G}$ students. Students rated the extent to which more textbooks to check out for classes would improve their library experience (response options were "a lot," "a little," "not at all," and "no opinion"). While continuing-generation students also report that an expanded Textbooks on Reserve Program would improve their library experience, $1 \mathrm{G}$ students said expanding the program would improve their library experience "a lot" at a rate $13 \%$ higher than non-1G peers (59\% to $46 \%$ ). Moreover, $1 \mathrm{G}$ students were more likely to report that the "print books, textbooks, and articles on reserve service" do not meet their needs (9\%), compared to continuing-generation students (4\%).

Some students described supportive professors. Others discussed feeling unwelcome and trapped when they sought understanding from professors for unaffordable textbook expenses.

"Right off the bat, I had so many expenses I hadn't experienced in high school. Students who can't pay for a $\$ 200$ textbook aren't welcome. I even talked to professors: ‘I can't afford this.' [They would reply], 'You're in this class, you have to get the books.' I went to a public high school. It was so weird to come to Duke and get zero support.”

\section{Findings related to the library experience}

Focus group participants and biennial survey respondents reported interacting with the Duke Libraries in diverse ways, reflecting the variety of services offered by the library.

Figure 3: Word cloud of how focus group respondents described the Duke Libraries

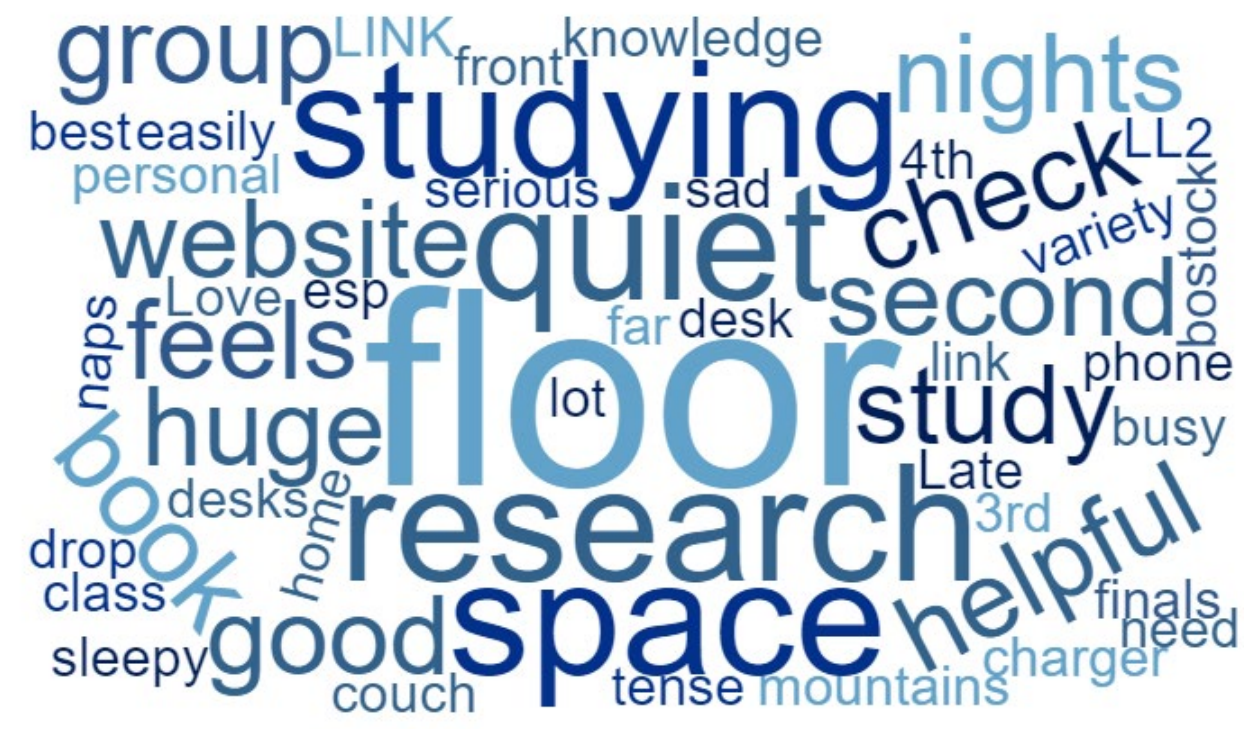

As reflected in Figure 3 above, many students value the libraries' physical spaces for studying and gathering:

"My day at Duke pretty much involves me going to class, and then me going to the library. And then, being there for pretty much the rest of the night. The library, for me, is a physical 
space to be. It's a bit of a home. When I walk into the library, there's a certain shift in attitude. Now, I know there are certain things I have to accomplish.”

Other students reported using library services such as printing, borrowing movies, chat assistance, leveraging librarian expertise, performing online research, borrowing technology like computers or phone chargers, and much more.

"I very, very highly utilize the library website. I have also utilized the librarians, particularly the History librarian. I was directed even further to a librarian who focuses on the Caribbean. That was insanely helpful, and it was mostly all online chat, but being directed online to great resources that we have access to has been insanely helpful to have the primary resources I need for a class project."

Results from the student survey support the idea that the libraries are an integral part of life on campus, with $80-85 \%$ of respondents agreeing with the statement that, "The library is an important part of my experience at Duke." However, continuing-generation students are more likely to "strongly agree" with this statement (50\%), compared to $1 \mathrm{G}$ students (40\%).

$1 \mathrm{G}$ students left 79 comments on the survey. Most comments from both $1 \mathrm{G}$ and continuing-generation students were in response to the question, "What are your ideas for making Duke Libraries more of a safe space?" While there is no single theme to $1 \mathrm{G}$ comments, many $1 \mathrm{G}$ students report that the libraries feel safe and welcoming. A few comments about the library as a safe space are listed below:

"Making Duke Libraries a safe space is a task for those who visit the library. While the staff and building itself are a 'safe space', the conversations that can be overheard in the library by other students/patrons are not always the most welcoming or inclusive. It will take an effort on the part of everyone and a campaign to raise awareness about the need for inclusivity and sensitivity to make the library a truly safe space on campus."

"Many of the groups on campus congregate and study together. While this is understandable, it can be daunting to walk into a room full of people who do not look like you or have similar experiences while searching for a seat. Overall, Duke Libraries are a safe space, and I think their displays and literature represent the broad perspectives of the student body."

"Overall, I believe that Duke University Libraries does a great job of assisting students and helping them to feel comfortable in what can be an extremely stressful environment. Not only do the libraries help our academic endeavors, they also assist with any other type of social support that students may need."

\section{Finding 5. IG challenges are challenges common to many Duke students.}

Broadly speaking, $1 \mathrm{G}$ students' survey responses did not differ from those of continuing-generation students. Both $1 \mathrm{G}$ and other students are generally confident in their ability to use library resources and report that they have successfully used the library and/or the library website to find research articles and books for class assignments. They find the website easy to use, believe that the library is welcoming, that library staff are helpful, and that the library is an important part of their experience at Duke.

Overall, the four areas in which more than $50 \%$ of all undergraduates responded that expanded services would improve their library experience "a lot" include:

- More spaces for quiet/individual study

- More textbooks to check out for my classes 
- Additional specialized spaces for honors researchers, graduate students, or other student populations

- M ore spaces for collaborative study

Survey data indicated a few differences between the services that $1 G$ and continuing-generation students believe to be important to their academics. Figure 4 shows services that $1 G$ students more frequently listed as "important" than continuing-generation students.

\section{Figure 4: Survey responses of services that are important to students}

\section{IMPORTANT TO YOUR RESEARCH, COURSEWORK, AND TEACHING}

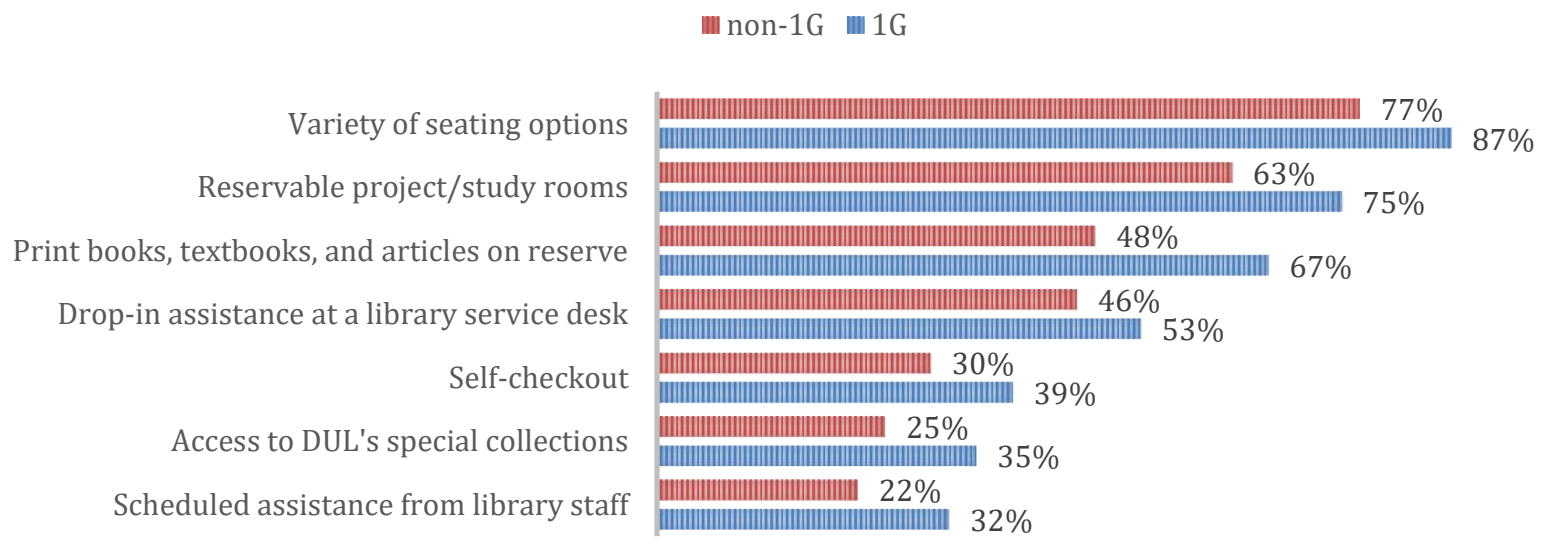

\section{I tems shown are those that reflect a greater than $10 \%$ difference between $1 \mathrm{G}$ and continuing- generation students.}

Student survey respondents were asked what existing services met or did not meet their needs at Perkins and Bostock Libraries. While students tended to feel similarly about these items, survey data indicates that two services are particularly important to $1 G$ students: the Textbooks on Reserve Program and the devicelending program. $1 \mathrm{G}$ students indicated that additional devices and equipment to check out would improve their library experience "a lot" at double the rate of continuing-generation students ( $26 \%$ versus $13 \%$ ). Among $1 \mathrm{G}$ students, the top requests were additional chargers for devices such as laptops and phones ( $21 \%$ of requests) and cameras (18\%).

Finding 6. It is sometimes hard to find existing resources at the library. As students progress in their academic careers at Duke, they often require more specific academic tools. On the way, they discover the wealth and depth of resources for rigorous academic research available to them at the library. While this process of discovery is typical of scholarly growth for all students, $1 \mathrm{G}$ students may particularly benefit from early knowledge and access to keystone academic supports and library services.

When asked about services they wish they had known about earlier, focus group participants mentioned the Textbooks on Reserve Program, library workshops (e.g., M atlab workshops), subject librarians, short-term lockers, and the ability to reserve study rooms. Students described numerous library resources they have discovered seemingly by chance or long after their first semester at Duke. At multiple points during the focus groups, students expressed that important services are not adequately marketed or shared with all $1 \mathrm{G}$ students. First-year 1G students reiterated the feeling of "unknown unknowns": of understanding that many resources are available, but often finding it difficult to locate specific points of access. 
Finding 7. Getting help from experts at the library is important, but difficult.

Students indicated they believe the best way to receive help is often to ask others, e.g., at a service desk, through chat, or via advising relationships. They also indicated, however, that reaching out to library staff can be intimidating or even frightening. They described an initial barrier to asking for help, even while knowing it is likely the best way to receive assistance. Students noted feeling that their questions are "silly," and they believe they have "gaps" in their knowledge. Students also reflected that it would be helpful for the person providing guidance to understand students' lack of familiarity with library resources and services.

"We have a librarian for an English department, and for the Linguistics department...but it would be awesome to have a $1 \mathrm{G}$ librarian. Just someone who already knows that we don't know anything, and it's okay."

\section{Finding 8. Checking out books using call numbers is daunting.}

Focus group participants frequently noted difficulty finding and checking out books using call numbers. $1 \mathrm{G}$ students did not pin this difficulty on library staff, but rather on their own lack of knowledge.

"The assumption is that we've been in libraries before. They [library staff] were helpful after I admitted I didn't know my way around."

The stacks are an understandably daunting environment, especially for those unfamiliar with academic libraries. Students reported feeling supported once they made their confusion clear.

"I remember them [library staff] just putting a number out in front of me. And I didn't know what to do with it. And I ask, 'Where do I find this?' And they're like, 'It's right there.' And I said, 'I don't know how to do this.' And that realization then washed over that person....And so they were helpful after I explained I didn't know what I was doing, but I don't think everyone can admit that they don't know how to use the system.

\section{Finding 9. While students generally view the library as a safe space, IG students feel less strongly that this is true.}

Some of the most striking differences in responses between $1 \mathrm{G}$ and continuing-generation students relate to the survey question about safe spaces. For the purposes of the user survey, a "safe space" was defined as a place in which people can feel safe from discrimination, harassment, and any other emotional or physical harm. Students were asked the degree to which they agree that Duke University and Duke University Libraries are safe spaces.

Only $20 \%$ of $1 \mathrm{G}$ students "strongly agree" that Duke Campus is a safe space for them, compared to $36 \%$ of continuing-generation students. While it is a small percent, four times as many $1 \mathrm{G}$ students (4\% compared to $1 \%$ ) "strongly disagree" that campus is a safe space for them. Duke University has some work to do before all students, and especially $1 \mathrm{G}$ students, feel that it is a safe space. These responses are shown in Figure 5. 
Figure 5: Survey responses, "For you, is Duke University a safe space?"

\section{DUKE UNIVERSITY IS A SAFE SPACE}

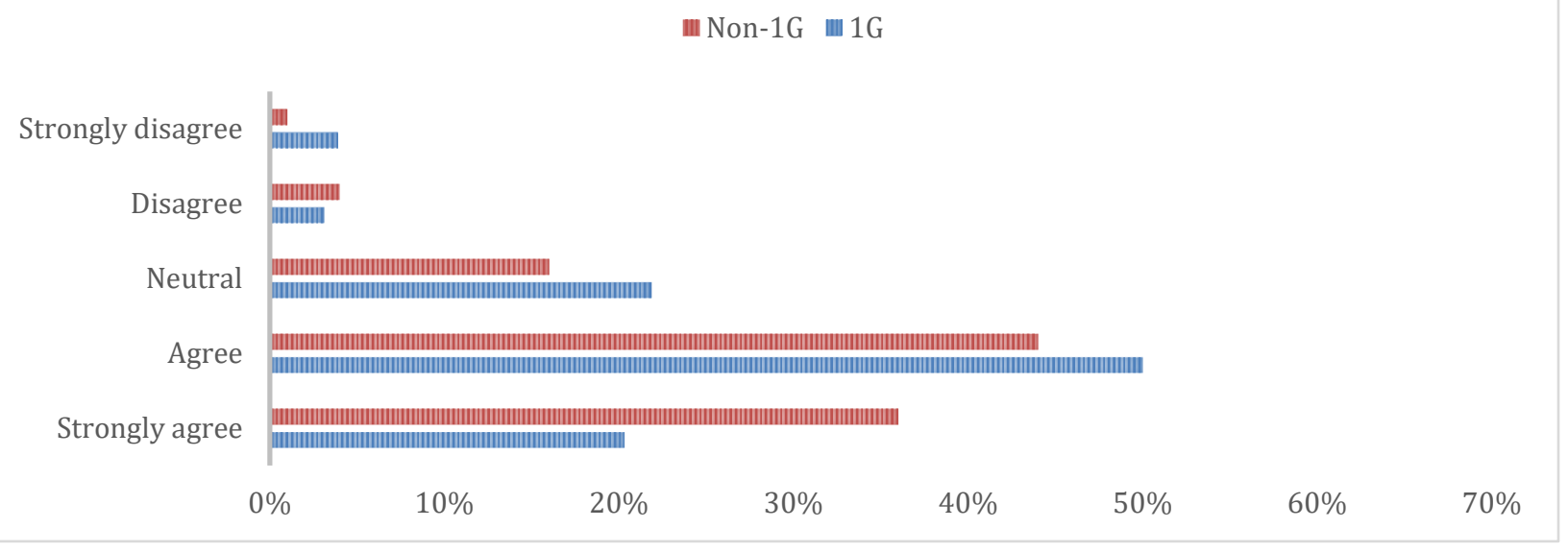

Both $1 \mathrm{G}$ and continuing-generation students feel strongly that the libraries are more of a safe space than Duke University. This is encouraging, as a major goal of the library is to provide a welcoming space for all. Differences in feelings about the library as a safe space between $1 \mathrm{G}$ and non-1G are less stark but still present: $52 \%$ of 1 G students "strongly agree" that the libraries are a safe space compared to $61 \%$ of continuinggeneration students (Figure 6).

Figure 6: Survey responses, "For you, is Duke Libraries a safe space?"

\section{DUKE LIBRARIES IS A SAFE SPACE}

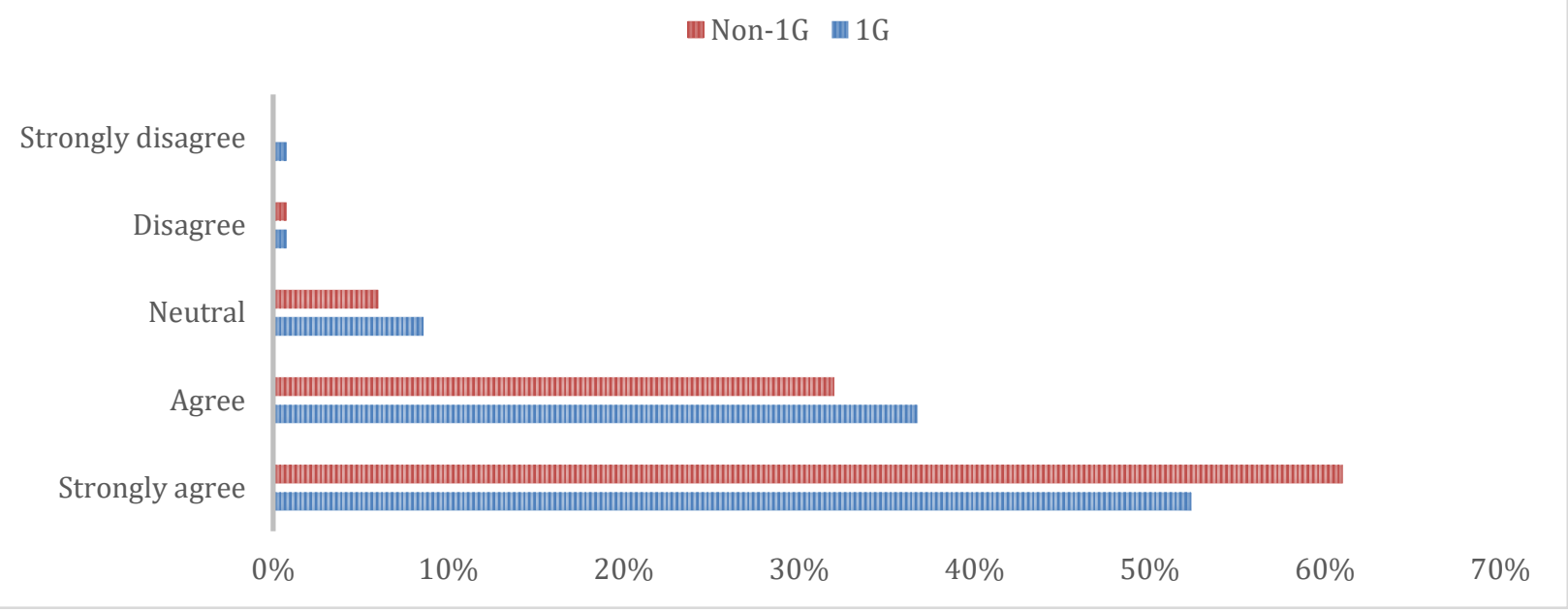

First-generation students are resilient and successful members of the Duke community. The early years on campus, which involve finding the right communities for support and learning new academic skills, can be a difficult transition for some. While all students experience challenges in college, $1 \mathrm{G}$ students may not have access to certain sources of information capital and can have significant financial stressors that are difficult for many peers to understand. The Duke University Libraries are well poised to support the success of $1 \mathrm{G}$ students on campus. Library staff can help reduce the burdens associated with transitioning from high school to college by making academic and research support known to students early and often, providing access to cost-prohibitive textbooks, and continuing to make the Duke Libraries a welcoming space for all students. 


\section{Next steps}

These findings became the basis of the 19 recommendations (Appendix E, Recommendations) outlined in the research team's full report. ${ }^{6}$ For example, one important recommendation was to expand the Textbooks on Reserve Program. ${ }^{7}$ Though the library already had a pilot program, it became clear that all students would benefit from expanding the program to include more textbooks and increasing marketing of the program. In fall 2018, the program expanded to include textbooks from the 100 largest courses on campus, and the library has already seen an increase in student use of these books. There was also a recommendation that a librarian be designated as a $1 \mathrm{G}$ student success librarian as a way to build the ecosystem of supportive offices and people described in focus groups. We hope to gain funding for a new full-time staff position in the future. In the meantime, the library has identified funding for a part-time internship for this purpose, and a member of the research team added this function to her numerous other responsibilities. In her capacity as the $1 \mathrm{G}$ student success librarian, she coordinates the libraries' efforts, makes connections with other programs and departments providing support, and serves as a point of contact for $1 \mathrm{G}$ students.

Additionally, the library formed a 1G Study Recommendations Implementation Team (headed by the 1G student success librarian) to prioritize recommendations and work across the library to improve services, library instruction, and marketing/outreach to $1 \mathrm{G}$ students. One of the team's first projects was to increase the library presence during the RS summer program. In addition to providing a library instruction session and one-on-one appointments with the students in this program, librarians attended a poster session and a mixer as a way to increase their presence. Also, the team is engaging with the staff dedicated to working on our service desks to find ways to help students feel more comfortable asking questions and navigating our book stacks. The team is pleased with their progress thus far and looks forward to finding new ways to connect with and support 1G students.

\section{Conclusion}

First-generation students are resilient and successful members of the Duke community. The early years on campus, which involve finding the right communities for support and learning new academic skills, can be a difficult transition for some. While all students experience challenges in college, $1 \mathrm{G}$ students may not have access to certain sources of information capital and can have significant financial stressors that are difficult for many peers to understand. The Duke University Libraries are poised to support the success of $1 \mathrm{G}$ students on campus. Library staff can help reduce the burdens associated with transitioning from high school to college by making academic and research support known to students early and often, exploring ways to make textbooks more affordable, and continuing to make the Duke Libraries a welcoming space for all students.

-Copyright 2019 Emily Daly, Joyce Chapman, Arianne Hartsell-Gundy, and Brenda Yang

\section{Endnotes}

1. The Consortium on Financing Higher Education (COFHE) is a voluntary, institutionally supported organization of thirty-five highly selective, private liberal arts colleges and universities. COFHE surveys provide for systematic examination of the undergraduate experience. See more at http://web.mit.edu/cofhe/.

2. The Office of Access \& Outreach (A\&O) has three full-time staff, two summer fellows, and a fellow director. $\mathrm{A} \& \mathrm{O}$ is responsible for supporting both first-generation and low-income students. While almost all 1G students at Duke are low-income, many low-income students are not 1G. See more at https://undergrad.duke.edu/office-access-outreach.

3. The Rubenstein Scholars (RS) Program is a merit scholarship and support program run by the Office of Access \& Outreach for exceptional, low-income, $1 \mathrm{G}$ students at Duke University. The program will begin its third year in the fall of 2018. The program includes a full scholarship, an intensive six-week summer program prior to the beginning of the first-year at Duke, mentorship, a laptop, and funding for summer professional opportunities. See more at https://rubensteinscholars.duke.edu/. 
4. Stacy Brinkman, Katie Gibson, and Jenny Presnell, "When the Helicopters Are Silent: The Information Seeking Strategies of First-Generation College Students," in Proceedings of the 2013 ACRL Conference: Imagine, Innovate, Inspire, April 10-13, Indianapolis, Indiana, ed. Dawn M. Mueller (Chicago: Association of College \& Research Libraries, 2013), 643, http://www.ala.org/acrl/sites/ala.org.acrl/files/content/conferences/confsandpreconfs/2013/papers/Bri nkmanGibsonPresnell_When.pdf.

5. See DUL Student Survey 2018 script at https://library.duke.edu/sites/default/files/dul/users/Joyce Chapman/Word versions.zip.

6. "Understanding the experiences and needs of $1 \mathrm{G}$ students at Duke," Duke University Libraries, last modified May 2018, https://dukespace.lib.duke.edu/dspace/handle/10161/17144.

7. “Top Textbooks at the Duke Libraries,” Duke University Libraries, accessed January 7, 2019, https://library.duke.edu/course-support/course-reserves/textbooks.

Appendix A: Selected bibliography

Logan, Firouzeh and Elizabeth Pickard. "First-Generation College Students: A Sketch of Their Research Process." In College Libraries and Student Culture: What We Now Know. Edited by Lynda M. Duke and Andrew D. Asher, 109-25. Chicago: American Library Association, 2012.

Focus: The Chronicle of Higher Education. How to Help First-Generation Students Succeed. February, 22, 2017. http://bit.ly/2CEH5DM.

McGrath, Maggie. "The Challenge of Being Poor at America's Richest Colleges.” Forbes. November 27, 2013. https://www.forbes.com/sites/maggiemcgrath/2013/11/27/the-challenge-of-being-poor-atamericas-richest-colleges/\#2594a9d0777d.

Zinshteyn, Mikhail. "How to Help First Generation Students Succeed." Atlantic, March 13, 2016. https://www.theatlantic.com/education/archive/2016/03/how-to-help-first-generation-studentssucceed $/ 473502 /$.

Stephens, Nicole M., Stephanie A. Fryberg, Hazel Rose Markus, Camille S. Johnson, and Rebecca Covarrubias. "Unseen Disadvantage: How American Universities' Focus on Independence Undermines the Academic Performance of First-Generation College Students." Journal of Personality and Social Psychology 102, no. 6 (2012): 1178-1197. https://doi:10.1037/a0027143.

Brinkman, Stacy, Katie Gibson, and Jenny Presnell. "When the Helicopters Are Silent: The Information Seeking Strategies of First-Generation College Students.” In Proceedings of the 2013 ACRL Conference: Imagine, Innovate, Inspire, April 10-13, Indianapolis, Indiana. Edited by Dawn M. Mueller, 643-50. Chicago: Association of College \& Research Libraries, 2013. http://www.ala.org/acrl/sites/ala.org.acrl/files/content/conferences/confsandpreconfs/2013/pap ers/BrinkmanGibsonPresnell_When.pdf.

Appendix B: Focus group script for sophomores, juniors, and seniors Introduction

Welcome, everyone, and thank you for being here. My name is [name], and I work in the Assessment \& User Experience here at Duke Libraries. Library staff are interested in learning more about the needs and experiences of particular groups of students here at Duke, and we're starting by talking with first-generation college students. Again, thank you for being part of today's focus group and sharing your experiences on campus and using the library. 
I will moderate today's session, and [name] will take notes and help watch the clock to make sure we stay on schedule. I have some questions to guide us through the discussion. Keep in mind that there are no right or wrong answers to any of these questions, and you don't have to answer every question.

First, just a few ground rules that we have found helpful in keeping these discussions productive [review ground rules]

\section{Discussion questions}

\begin{tabular}{|c|c|}
\hline $\begin{array}{l}\text { Warm-up } \\
(5 \mathrm{~min})\end{array}$ & $\begin{array}{l}\text { 1. Brief intro from moderator } \\
\text { 2. Brief intros from participants: Name and hometown. } \\
\text { End brief intros with more info from the moderator or note taker to model openness and } \\
\text { vulnerability. } \\
\text { 3. POST-IT: Think about the people, services, or spaces you feel are most } \\
\text { supportive and safe at Duke. Take a moment to write these down, one idea per } \\
\text { post-it. We'll be discussing these later but not posting them anywhere. }\end{array}$ \\
\hline $\begin{array}{l}\text { First year } \\
\text { experience }\end{array}$ & $\begin{array}{l}\text { 1. SCRATCH PAPER: What did you find easiest about your first semester (or year) } \\
\text { at Duke? Take a moment to write your thoughts on the blank paper in front of } \\
\text { you; then we'll discuss as a group. } \\
\text { 2. SCRATCH PAPER: What did you find most challenging during your first } \\
\text { semester (or year) at Duke? Take a moment to write your thoughts on the blank } \\
\text { paper in front of you; then we'll discuss as a group. }\end{array}$ \\
\hline $\begin{array}{l}\text { Belonging-self } \\
\text { perception }\end{array}$ & $\begin{array}{l}\text { 1. What has made you feel welcome at Duke? } \\
\text { 2. What has made you feel unwelcome at Duke? } \\
\text { 3. What makes the people, services, or spaces that you just wrote out on post-its } \\
\text { particularly safe and supportive? }\end{array}$ \\
\hline $\begin{array}{l}\text { Informed-self- } \\
\text { perception and } \\
\text { reflection } \\
\text { (college) }\end{array}$ & $\begin{array}{l}\text { 1. Have you ever felt like other people around you know things about college that } \\
\text { you don't know about? } \\
\text { 2. If so, what are some of the things others seemed to know about that you did not? }\end{array}$ \\
\hline Info seeking & $\begin{array}{l}\text { 1. Since you've been at Duke, what do you do if you have questions or concerns } \\
\text { about college? } \\
\text { 2. Is there a person, group, office, or place you usually go to? } \\
\text { 3. If so, describe this person, group, office, or place and a time you went to that } \\
\text { person or place for help. }\end{array}$ \\
\hline
\end{tabular}




\begin{tabular}{|c|c|}
\hline $\begin{array}{l}\text { Library- } \\
\text { experience and } \\
\text { first reaction }\end{array}$ & $\begin{array}{l}\text { 1. POST-IT: What words or feelings come to mind when you think about the } \\
\text { libraries at Duke? Take a moment to write these down, one idea per post-it. We'll be } \\
\text { discussing these later but not posting them anywhere. } \\
\text { 2. Have you used the libraries at Duke? If so, describe how you use them. } \\
\text { 3. What works well for you? } \\
\text { 4. What does not work well? }\end{array}$ \\
\hline Research anxiety & $\begin{array}{l}\text { 1. What kinds of research do you do? } \\
\text { 2. What do you find most positive or exciting about doing research? } \\
\text { 3. What do you find most confusing, challenging, or uncomfortable about doing } \\
\text { research? }\end{array}$ \\
\hline $\begin{array}{l}\text { Informed- } \\
\text { reflection } \\
\text { (libraries) }\end{array}$ & $\begin{array}{l}\text { 1. Are there things that you know now about the libraries at Duke that you wish } \\
\text { you had known before you started at Duke? } \\
\text { 2. If so, what are those things? } \\
\text { 3. How did you come to know them? }\end{array}$ \\
\hline
\end{tabular}

\section{Conclusion}

Those are all the questions I have. I've really enjoyed talking with you this afternoon/evening. Thank you for taking the time to meet with us. I'd be happy to stay after this session or meet with you later if you'd like to share anything else.

\section{Appendix C: Focus group script for first-year students}

Introduction

Welcome, everyone, and thank you for being here. My name is Emily, and I'm Head of Assessment \& User Experience here at Duke Libraries. Library staff are interested in learning more about the needs and experiences of particular groups of students here at Duke, and today we're talking with first-year firstgeneration college students. Again, thank you for being part of today's focus group and sharing your experiences on campus and using the library.

I will moderate today's session, and Ira will take notes and help watch the clock to make sure we stay on schedule. I have some questions to guide us through the discussion. Keep in mind that there are no right or wrong answers to any of these questions, and you don't have to answer every question. 


\section{Discussion questions}

\begin{tabular}{|l|l|}
\hline $\begin{array}{l}\text { Warm-up } \\
(5 \mathrm{~min})\end{array}$ & $\begin{array}{l}\text { 1. } \quad \text { Brief intro from moderator } \\
\end{array}$ \\
& $\begin{array}{l}\text { End brief intros with more info from the moderator or note taker to model openness and } \\
\text { vulnerability. }\end{array}$
\end{tabular}

3. POST-IT: Think about the people, services, or spaces you feel are most supportive and safe at Duke. Take a moment to write these down, one idea per post-it. We'll be discussing these later but not posting them anywhere.

\begin{tabular}{|c|c|}
\hline $\begin{array}{l}\text { First year } \\
\text { experience }\end{array}$ & $\begin{array}{l}\text { 1. SCRATCH PAPER: What did you find easiest about your first semester at Duke? } \\
\text { Take a moment to write your thoughts on the blank paper in front of you; then we'll } \\
\text { discuss as a group. } \\
\text { 2. SCRATCH PAPER: What did you find most challenging during your first semester at } \\
\text { Duke? Take a moment to write your thoughts on the blank paper in front of you; then } \\
\text { we'll discuss as a group. }\end{array}$ \\
\hline $\begin{array}{l}\text { Belonging-self } \\
\text { perception }\end{array}$ & $\begin{array}{l}\text { 1. What has made you feel welcome at Duke? } \\
\text { 2. What has made you feel unwelcome at Duke? } \\
\text { 3. What makes the people, services, or spaces that you just wrote out on post-its } \\
\text { particularly safe and supportive? }\end{array}$ \\
\hline $\begin{array}{l}\text { Informed-self- } \\
\text { perception and } \\
\text { reflection } \\
\text { (college) }\end{array}$ & $\begin{array}{l}\text { 1. Have you ever felt like other people around you know things about college that you } \\
\text { don't know about? } \\
\text { 2. If so, what are some of the things others seemed to know about that you did not? }\end{array}$ \\
\hline Info seeking & $\begin{array}{l}\text { 1. Since you've been at Duke, what do you do if you have questions or concerns about } \\
\text { college? } \\
\text { 2. Is there a person, group, office, or place you usually go to? } \\
\text { 3. If so, describe this person, group, office, or place and a time you went to that person } \\
\text { or place for help. }\end{array}$ \\
\hline
\end{tabular}




\begin{tabular}{|c|c|}
\hline $\begin{array}{l}\text { Library- } \\
\text { experience and } \\
\text { first reaction }\end{array}$ & $\begin{array}{l}\text { 1. POST-IT: What words or feelings come to mind when you think about libraries? } \\
\text { These can be the libraries at Duke or libraries you used before coming to Duke. Take } \\
\text { a moment to write these down, one idea per post-it. Write "Duke" at the top of the } \\
\text { post-its that refer to feelings or words about Duke Libraries. We'll be discussing } \\
\text { these later but not posting them anywhere. } \\
\text { 2. Have you used the libraries at Duke? If so, describe how you use them. } \\
\text { 3. What works well for you? } \\
\text { 4. What does not work well? } \\
\text { 5. How do the libraries at Duke compare to libraries you used before coming to Duke, } \\
\text { perhaps during high school? }\end{array}$ \\
\hline $\begin{array}{l}\text { Research } \\
\text { anxiety }\end{array}$ & $\begin{array}{l}\text { 1. What kinds of research have you done during your first year at Duke? } \\
\text { 2. What do you find most positive or exciting about doing research? } \\
\text { 3. What do you find most confusing, challenging, or uncomfortable about doing } \\
\text { research? } \\
\text { a. Prompt, if needed: What services have helped you learn to do research or use } \\
\text { the library? [students might mention Wr101, library orientation programs, or } \\
\text { Focus here]. What other services might help first-year students learn to do } \\
\text { research or use the library? }\end{array}$ \\
\hline $\begin{array}{l}\text { Informed- } \\
\text { reflection } \\
\text { (libraries) }\end{array}$ & $\begin{array}{l}\text { 1. Are there things you've learned about the libraries at Duke during your first semester } \\
\text { and a half that you wish you had known when you started in August? } \\
\text { 2. If so, what are those things? } \\
\text { 3. How did you come to know them? }\end{array}$ \\
\hline
\end{tabular}

\section{Conclusion}

Those are all the questions I have. I've really enjoyed talking with you this afternoon/evening. Thank you for taking the time to meet with us. I'd be happy to stay after this session or meet with you later if you'd like to share anything else. 


\section{Appendix D: Recruitment email}

Dear [First name],

We need your help. We (the staff at Duke University Libraries) are trying to better understand the unique needs of the students we serve, beginning with a focus on first-generation college students. Your input will help us improve library services, spaces, and resources to better meet your needs.

Would you be willing to participate in a focus group at the library with 3-6 other first-generation college students? Once we have a list of potential participants, we will schedule the discussion at a time (likely before Fall Break) that works best for the majority of volunteers. The focus group will last 90 minutes and will include a catered lunch or dinner. We understand that you might not be able to participate once the exact date and time are set, and that's OK-just let us know if you are interested!

If you are interested in participating, please RSVP by the end of day Tuesday, September 12th. Feel free to let me know if you have any questions or concerns.

\section{RSVP now}

\section{Yes, I would like to participate in a focus group}

No, I do not want to participate in a focus group

Depending on interest, we may not be able to accommodate everyone who volunteers due to size constraints. Thank you for considering, and for helping Duke Libraries staff better meet your needs!

Joyce Chapman

Assessment \& User Experience Department

Duke University Libraries

Your privacy is important to us:

We truly value the many unique perspectives that students bring to Duke, and it is important to the Libraries to understand all students' experiences, backgrounds, and information needs. We hope you will consider joining us. While the Libraries will summarize what we learn from the focus groups in a report that will be shared internally with library staff as well as with the Office of Access \& Outreach, your participation in the focus group will be confidential. Participants' names will not be included in any report, and your name will not be associated with anything you say. However, you will not be anonymous to your fellow focus group participants during the discussion. We will ask everyone present to please keep what is said confidential out of respect for each other. 


\section{Appendix E: Recommendations}

1. Designate a $1 \mathrm{G}$ student success librarian

2. Offer library and research training sessions designated for $1 \mathrm{G}$ students

3. Participate in Duke's 1G pre-orientation sessions

4. Advertise library services that may be particularly appealing to $1 \mathrm{G}$ students

5. Expand the Textbooks on Reserve Program

6. Advertise the existing Textbooks on Reserve Program to 1G students

7. Investigate ways to make the libraries feel like more of a safe space for all students

8. Encourage all staff and students who work at service desks to be aware that many students come to Duke with little experience using academic libraries

9. Develop general guidelines for staff regarding the information they provide about public scanners

10. Investigate possibilities to expand the device lending program

11. Research the possibility of a dedicated study and storage space for $1 \mathrm{G}$ students

12. Develop a peer mentor program for conducting library research

13. Send a letter from the university librarian to $1 \mathrm{G}$ students' families

14. Advertise the libraries' student advisory boards to $1 \mathrm{G}$ students

15. Advertise student library jobs on the $1 \mathrm{G}$ listserv

16. Collaborate with campus partners to advertise library services to $1 \mathrm{G}$ students

17. Communicate this report and its findings to focus group participants, $1 \mathrm{G}$ students, and campus staff who work with $1 \mathrm{G}$ students

18. Communicate this report and its findings to other campus stakeholders

19. Conduct ongoing assessment with $1 \mathrm{G}$ students 